\title{
Heraclides of Pontus and the Idomeneus Myth ${ }^{\star}$
}

\author{
Anastasiia V.Pavlova \\ St. Petersburg State University, \\ 7-9, Universitetskaya nab., St. Petersburg, 199034, Russian Federation; a.v.pavlova@mail.ru
}

For citation: Anastasiia V. Pavlova. Heraclides of Pontus and the Idomeneus Myth. Philologia Classica 2020, 15 (1), 47-53. https://doi.org/10.21638/spbu20.2020.104

\begin{abstract}
Heraclides of Pontus, a versatile philosopher whose work still remains largely unexplored, wrote several pieces on Homer including "Solutions of the Homeric problems", to which some of the extant fragments are attributed. One of these (F.171 Wehrli = 99 Schütrumpf) concerns the Iliad and the Odyssey being discrepant in the number of the cities on Crete: the Catalogue

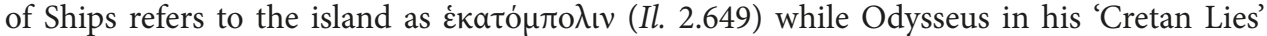
states that people dwell ninety great cities on Crete (Od.19.174). To explain this inconsistency, Heraclides tells a dramatic story about Idomeneus which he probably made up himself, being an eminent author of dialogues and even tragedies (provided that the relevant testimonies are reliable) with an interest in mythology. His version of Idomeneus' homecoming was not supported by contemporary historians, and, although later picked up by some poets and scholars, did not end up as a part of the commonplace Idomeneus tradition as we know it today.
\end{abstract}

Keywords: ancient literature, literary criticism, Homer studies, Heraclides of Pontus.

Heraclides of Pontus was once called one of the most enigmatic figures in the history of Greek philosophy. ${ }^{1} \mathrm{He}$ was known as a prolific author; his treatises were read up until the late antiquity. Yet, none of his works survived, his biography remains fragmentary and his teachings cannot be easily reconstructed, the testimonies being mostly vague and sometimes conflicting. Diogenes Laertius (5. 86) mentions a huge amount of Heraclides' writings in different areas of knowledge, comprising geometry and physics, dialectics, ethics, grammar, music and literary criticism, history and rhetorics. The catalogue has been criticized for a number of reasons, ${ }^{2}$ but Heraclides' scientific versatility remains beyond doubt.

Among Heraclides' writings on grammar and criticism, Diogenes mentions several works on Homer's poems, including two books of Solutions of Homeric Problems. The name implies that Heraclides contributed to the well-known philological genre of resolving inconcistencies in Homer. Five or six of the extant Heraclides' fragments found in the

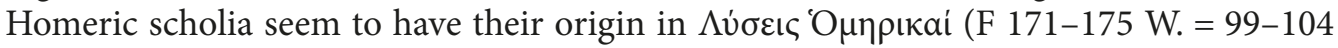
Schütr.; Schütrumpf also adds fragment 103 to Wehrli's list).

The fragment cited below is taken from Schol. Venet. B in Il. 2, 649 and can be traced

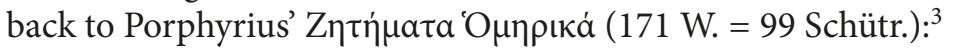

* This article was prepared within the framework of Russian Foundation for Basic Research (RFBR) research project № 19-312-90026.

1 Gottschalk 1980, 1.

2 Wehrli 1953, 64-65 with references; see also Gottschalk 1980, 6.

${ }^{3}$ Quoted after Schütrumpf 2008; see also Schrader 1880, 48.25-49.7.

(C) St. Petersburg State University, 2020 


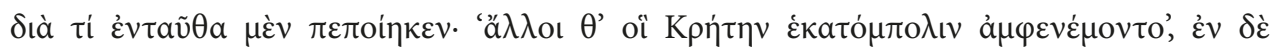

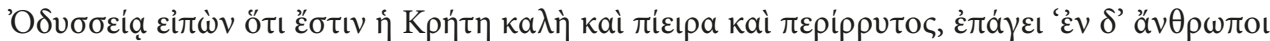

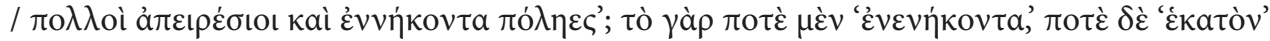

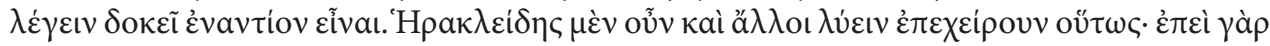

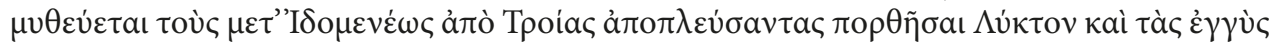

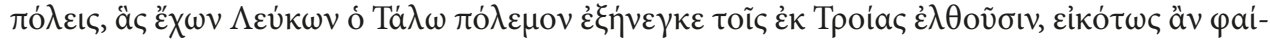

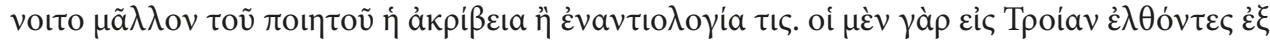

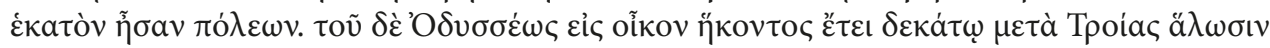

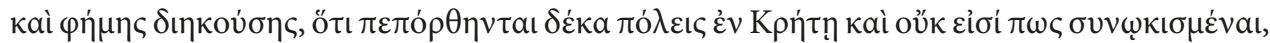

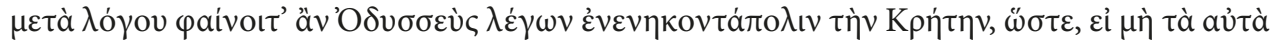

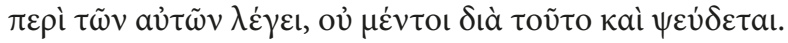

Why did he (scil. Homer) write here: "and others who dwell Crete of hundred cities", but in the Odyssey, after saying that Crete is beautiful and prosperous and surrounded by water, adds: "and there are innumerable people and ninety cities". Because it seems to be a contradiction to say "ninety" in one instance and "hundred" in another. However, Heraclides and others tried to solve it like this: since, he tells, those who came back from Troy with Idomeneus destroyed Lyktos and some cities nearby which Leucon, son of Talas, was occupying when he started a war against those who came from Troy, it seems to be much more a precision of the poet, rather than a kind of contradiction. That is why those who left to Troy were from hundred cities, but when Odysseus was on his way home ten years after the capture of Troy and the rumor went round that ten cities on Crete were destroyed and were not united in any way, so Odysseus seems to say for a reason that Crete has ninety cities; so that even if the poet does not say the same about the same things, he still does not lie about that. ${ }^{4}$

The problem of why the number of cities on Crete in the Iliad (2.649) and in the Odyssey (19. 174) is different seems to be well-known among the ancient as well as modern scholars. ${ }^{5}$ Aristotle, quoted by Porphyrius (Gigon $370=$ Rose 129 ), ${ }^{6}$ suggests a number of possible explanations:

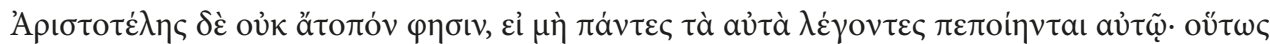

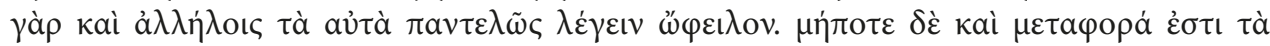

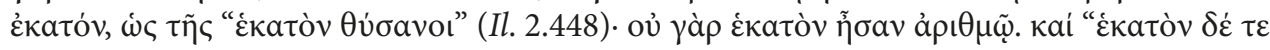

${ }^{4}$ All translations mine - A.P.

${ }^{5}$ In his most recent commentary on the Catalogue of Ships, E. Visser makes a comprehensive overview of the "Cretan" part of the Catalogue. Commenting on the problem of the number of cities, he suggests that the Catalogue is based on a myth, hence $\dot{\varepsilon} \kappa \alpha \tau$ ' $\mu \pi \mathrm{r} \lambda ı$, the standard mythological epithet for Crete, is used, whereas the Odyssey narrative is much closer to real historical and geographical facts (see Visser 1997, 613-619; esp. 618 with the footnote). Visser assumes that the 90 cities on Crete mentioned in the Odyssey can be treated as an attempt to correct the mythological formula (though as ingenious as it might be, this assumption presumes some other presuppositions to be correct). Other modern commentaries are rather focused on the historical authenticity of the facts mentioned in the Catalogue and in the Odyssey along with the ethnical diversity of Cretans, and usually do not pay much attention to the "number of cities" inconsistency (Kirk 1995, 184, 223-224; Heubeck 2002, 84-85). Referring to Odyssey 19.174, Kirk says there must have been ninety cities on Crete indeed (Kirk 1995, 224). The heterogeneity of the Catalogue should also be taken into account; if it does really include later interpolations, "Crete of hundred cities" might be one of them.

${ }^{6}$ Quoted after Gigon 1987. Rose curtails the fragment after $\ddot{\omega} \varphi \varepsilon \iota \lambda o v$; it was supposed to be a mistake by M. Heath who insists that Aristotle's solutions were written in response to Heraclides (see Heath 2009, disagreement with Rose is expressed on p. 255). Flashar, in his edition, followed Rose (see Flashar et al. 2006, 305). Gigon includes the whole passage. The fragment has a parallel in the section of Aristotelian Poetics where metaphors are discussed (XXI 1457b11-13). 


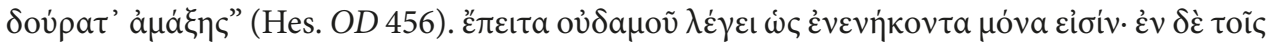

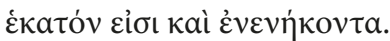

Aristotle says there is nothing strange about having all pictured characters tell not the same things as the poet does, because otherwise they most certainly would have to tell the same things to each other; perhaps "one hundred" is a metaphor like "hundred fringes" (Il. 2.448), for there were not one hundred of them; and also "there are hundred timbers in the wagon" (Hes. OD 456). Moreover, he did not say there were only ninety, for one hundred contains ninety as well.

Another attempts to explain this inconsistency include Ephorus, who claims that the ten cities were founded later by the Dorians who came with Althaemenes the Argive after the Trojan War (Strab. 10.4.15= FGrHist 70 F 146), and Sch. Vet. ad Il. 2.649 (I 318 Erbse)

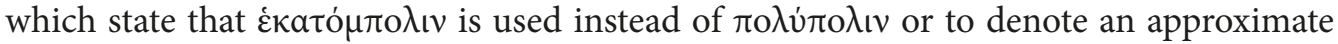
number. The latter solution probably traces back to Aristonicus of Alexandria, but basically follows the lead of Aristotle labelling "one hundred" as metaphor in the fragment

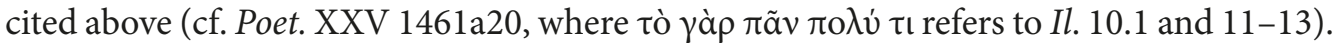

It is well-attested that Heraclides posessed considerable literary talent. His writings

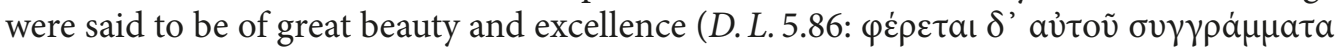

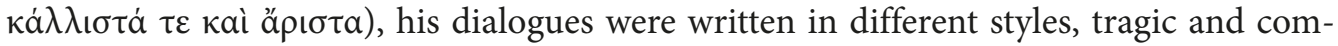
ic, while he also had an "intermediate style of speech". Besides, he was inventive, prone

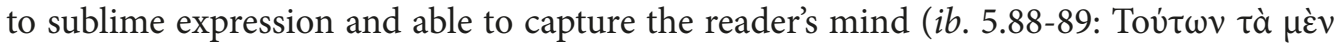

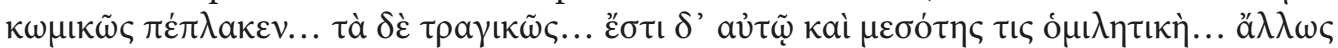

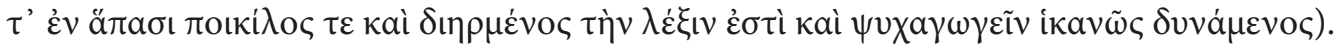
Cicero, who calls him vir doctus in primis (Tusc. 5.3.8 [F 88 Wehrli=85 Schütrumpf]), re-

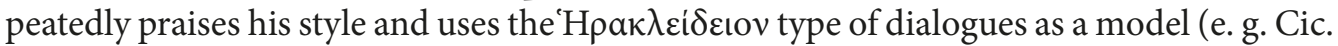
Att. 15.4.3 [27b W.=21C Schütr.]; 15.13.3 [27d W.=21D Schütr.]; 15.27.2 [27a W.=21A Schütr.]; 16.2.6 [27c W. $=21 \mathrm{~B}$ Schütr.]). ${ }^{8} \mathrm{H}$. Gottschalk reasonably assumes that ancient critics regarded Heraclides' writings as fiction rather than philosophy, since the best attested fact about him is that he was an eminent writer. ${ }^{9}$

His main genre was probably dialogue, but, unlike the dialogues of Aristotle and other peripatetics who chose their contemporaries as interlocutors, these dialogues were set in unconventional locations and involved antiquae personae (24 W. = 19A Schütr.), fantastic motives and other exotic details. ${ }^{10}$ Aulus Gellius describes one of Heraclides' stories as

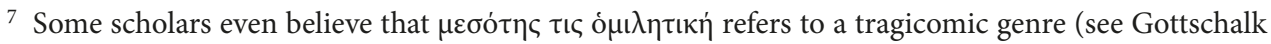
1980, 7 with references).

${ }^{8}$ It is from Cicero that we know the most about Heraclides' literary character. In his letters to Atticus,

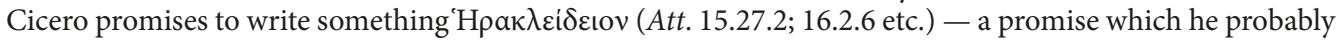
never fulfilled (cf. Shakleton Bailey 1967, 295). Gottschalk $(1980,9)$ argues that the composition of Cicero's dialogues is quite similar to the composition of the dialogues of Platos followers, with Socrates not being the central figure anymore and each one of the characters usually holding their speech one after another. Heraclides' dialogues probably followed the same structure, despite introducing unusual interlocutors and settings. Cicero's De Republica is regarded by Gottschalk as the most "Heraclidean".

${ }^{9}$ Gottschalk 1980, 8.

10 See also Wehrli 1968, 678-679; Gottschalk 1980, 9. Heraclides' characters were Zoroaster (71 W. = 79 Schütr.), a magus (69 W. = 139 Schütr.; Wehrli $[1953,83]$ believes him to be the same Zoroaster), a divine spirit turned into a young man $(75 \mathrm{~W} .=132$ Schütr. $)$ et sim.; some of his dialogues are set in the Underworld (71-72 W. = 79-80 Schütr.). 
iucunda memoratu et miranda (Noct. Att. 8.15 [F 26 W. = 20 Schütr.] and Plutarch speaks

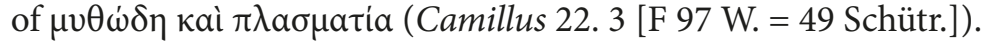

Heraclides' interest in tragedy and history of literature is also well-known: along with other works on Homer, ${ }^{11}$ Diogenes mentions On the passages in Euripides and Sophocles in three books, one book On the Three Tragic Poets (which is, in fact, the earliest testimony on the Athenian canon of three great tragic poets) ${ }^{12}$ and On Poetry and Poets also in one book. According to Proclus, Heraclides himself told that he had once been sent by Plato to Colophon to collect the poems of Antimachus (6 W. $=8$ Schütr.). Still, none of the extant fragments of Heraclides can be decisively attributed to any of the treatises mentioned above.

Yet another testimony on Heraclides' historical and literary engagements comes from Diogenes Laertius 5. 92: Aristoxenus allegedly said once that Heraclides wrote tragedies and misrepresented them as written by Thespis (181 W. $=1(92)$ Schütr.).

Thus, Heraclides could solve the problem of Cretan cities in his own creative way. His explanation appears to be more historical than linguistic, which brings him close to the literary criticism of the younger peripatetics. ${ }^{13}$ His version is overly rich in detail and as opposed to Aristotle and Ephorus - too excessive for an explanation of such a minor inconsistency. This strongly suggests that in order to harmonise the two versions he told a dramatic story fully made up by himself.

This possibility is further corroborated by the fact that Heraclides' rendition of the Idomeneus' homecoming myth seems to be unique across the archaic-classical tradition and is never mentioned by his contemporaries. Other known versions of the story are totally different from Heraclides' narration. ${ }^{14}$

Homer tells that Idomeneus came back to Crete happily with all his fellows, "and

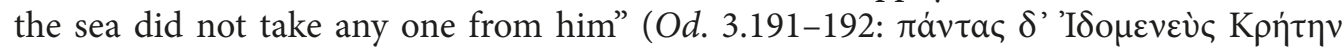

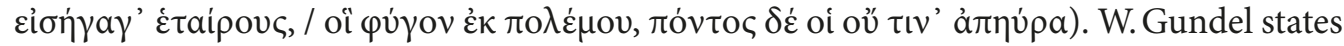
that the incongruity between the two poems concerning the number of Cretan cities enabled later authors to find new themes and storylines about Idomeneus' misfortunes, as for instance, that he was expelled from his homeland and the ten cities were destroyed. ${ }^{15}$ On the other hand, the Odyssey could have given rise to a literary tradition which (according to A.Rzach's reconstruction) was later combined into Nostoi. ${ }^{16}$ The Nostoi-authors could have concocted a new version of the Idomeneus myth, whether related to the Homeric problem or not. Anyway, none of the extant fragments of the archaic epic poems contain a single reference to Idomeneus, ${ }^{17}$ except for the Pseudo-Hesiodean Catalogue of

${ }^{11}$ I. e. two books On the Age of Homer and Hesiod and two books On Archilochus and Homer (Diog. Laert. Ibid.). According to Diogenes, Chamaeleon the peripatetic accused Heraclides of stealing from him the material for books on Homer and Hesiod (176 W. = 1 Schütr.).

12 See Wehrli 1953, 123.

13 On Heraclides and peripatetic literary studies, see Wehrli 1968, 682-684; Podlecki 1969, 115-117; Gottschalk 1980, 136; Kennedy 1993, 200-219, esp. 205.

14 The sources are summarized by Drexler $(1894,106-108)$, Gundel $(1914,906-909)$, Hornblower (2017, 210-213; 434-435) and Gantz (1993, 697-699). Strangely enough, none of the scholars mentioned make reference to the Heraclides' fragment, although its authenticity has never been doubted.

15 Gundel 1914, 908, 47-52.

16 Rzach 1922, 2422-23.

17 West 2003. Crete is mentioned in one of the fragments of Cypria (Cypr. Arg. 2, West 2003, 68 = Proclus, Chrestomatia, suppl. ex Apoll. epit. 3. 2). According to the 'Chrestomathy of Proclus', Menelaus went to Crete for the funeral of his grandfather Catreus and left Helen with Alexander. 
Women, which mentions the fact that Idomeneus himself came from Crete to seek Helen's hand. ${ }^{18}$ This passage is presumed to have gone on with an excursus on the history and state of Crete, but the following text is lost, so it is unknown if the author of the Catalogue mentioned the quantity of the cities and provided an approach to solving the problem in Homer.

Strabo, referring to the Ephorus' explanation (i. e. that 10 cities were founded later), assumes that 90 cities existed on Crete during the Trojan War and 100 by the time of Homer (10.4.15). He sketches a story (similar to that of Heraclides though his name is not mentioned) of how these were destroyed by Idomeneus' rivals, and condemns it as false, since otherwise Homer would probably have mentioned it. His further argument is that, returning from Troy, Idomeneus' army was so strong that no rival could have overpowered it. Heraclides tells that the cities were destroyed by Idomeneus himself, because Leukos captured them and started the war. However, Strabo apparently supports the version according to which the cities were destroyed after Idomeneus came back from Troy. It is thus not that important which of the parties was held responsible for destroying the cities. Significantly more important is the fact that the timeline suggested by Strabo matches the timeline in Heraclides' story.

According to Diodorus Siculus (5.79.4), Idomeneus died and was buried on Crete together with Meriones; after their death they were treated as heroes by the Cretans. Diktys mentions nothing of Idomeneus' adventures after the war despite being his fellow, ${ }^{19}$ while Hyginus and Quintus Smyrnaeus follow suit. ${ }^{20}$

In the Hellenistic age, the Heraclides-derived story of Idomeneus' misfortunes was picked up by Lykophron in Alexandra: troubles of Idomeneus are detailed in verses 12141225 , while in verses $430-431$ he is said to be buried in the woods of Kerkaphos near Kolophon. ${ }^{21}$ The same is reflected in Scholia vetera to the poem. The motive was developed by Apollodoros, and in the Middle Ages by Tzetzes (in his commentary on Lykophron and in the Chiliades) and Eustathius. New details were gradually added to the story: in Alexandra, Leucus is called the guardian of the kingdom ${ }^{22}$ who killed Idomeneus' wife Meda and their daughter Kleisithera. ${ }^{23}$ In Apollodorus (Ep. 22.4-5) ${ }^{24}$ and Tzetzes, Leucus was supported by Nauplios. It remains unclear how exactly the conflict was solved. Scholia

18 See Merkelbach, West 1967, fr. 204.56-64.

19 Gantz $(1993,698)$ finds it surprising, although the main subject of Diktys' novel is actually the Trojan War, not the after-war episodes.

20 Both authors only mention Idomeneus taking part in battles. In Quintus Smyrnaeus's poem, Idomeneus also wants to partake in the contest at Achilles' funeral, but none of the contestants is willing to compete with him for he is older (Quint. Smyrn. 4. 284-286). Hyginus also focuses on Idomeneus' activities during the war (LXXXI; XCVII; CXIIII; CCLXX, numeration by Schmidt 1872).

${ }_{21}$ Though, if we may credit the above-mentioned testimony of Diodorus, the Cretans continued to point out the tomb of Idomeneus in Knossos; Diodorus even quotes the epitaph on the tomb.

${ }^{22}$ This Leukos is an obscure character: according to Roscher's lexicon, all that is known about him can be found either in the Schol. to Il. 2.649 (i.e. from Heraclides's story) or in later authors who turned to the myth of Idomeneus, like Pseudo-Apollodorus or Tzetzes in his commentary on Lycophron (Stoll 1897, 2011, 15-20).

${ }^{23}$ Hornblower $(2017,435)$ qualifies them as minor and little-known. Odyssey only mentions Orsilochos, the son of Idomeneus, whom Odysseus claims to have murdered ( $O d .13 .260)$.

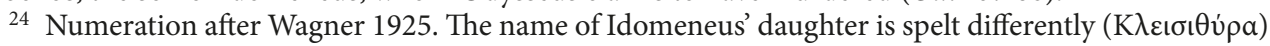
by Apollodoros. It is worth noting that in his list of women corrupted by Nauplios, Agamemnon's wife Klytaimnestra is also mentioned along with Idomeneus' wife Meda. 
vetera and Tzetzes tell that Idomeneus blinded Leucus before leaving, ${ }^{25}$ Apollodoros does not allude to this.

Virgil mentions Idomeneus several times in the Aeneid, ${ }^{26}$ most tellingly in $3.121-122$ :

fama volat pulsum regnis cessisse paternis
Idomenea ducem, desertaque litora Cretae,
hoste vacare domos, sedesque adstare relictas.

There is a rumor flying around that king Idomeneus was expelled from his paternal kingdom and the shores of Crete are abandoned and the palace is free from the foe and the dwellings are empty. ${ }^{27}$

Virgil does not tell why Idomeneus was expelled, thus giving no insight into the relevant myth. It was, however, provided by Servius: on his way back, Idomeneus prays to Poseidon during the tempest and promises to sacrifice to him the first one whom he will meet after landing. On shore, he meets his son and, shortly afterwards, a plague strikes Crete (it is not known whether he killed his son or not). Idomeneus is then expelled and first dwells in Sallentinum, then leaves to Kolophon. ${ }^{28}$ This version, well-known from European Classicist literature and opera, ${ }^{29}$ appears only in Servius. His sources remain as yet obscure, and there are those who argue that it was introduced by him on his own risk. ${ }^{30}$ Servius' version might align with the Nostoi (Idomeneus meets a storm ${ }^{31}$ ), but contradicts Homer and Heraclides (the hero arrives home safely). Modern scholars apply an 'anthropological' approach sharing the opinion that myths of Idomeneus were used to explain the expansion of certain religious cults in South Italy and Asia Minor, for, according to the late tradition, Idomeneus founded some sanctuaries in places of his exile. ${ }^{32}$

To conclude, the earlier and lesser-known variant of Idomeneus' after-war adventures than the popular one, which stems from Servius, was first introduced by Heraclides in his

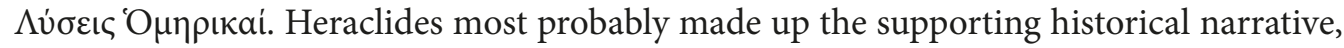
his starting point being the desire to solve the inconsistency in Homer's poems. The story

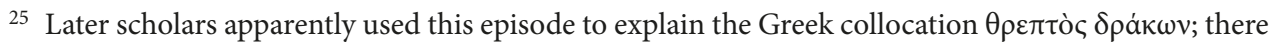
is another myth on Idomeneus, Thetis and Medea which is etiological for the proverb that all Cretans lie; see Drexler 1894, 108, 6-39; Grundel 1914, 908, 13-33 with references to Ptolemaeus Chennus (Nov.Hist.5) and Schol. vet. ad Lycophr.

26 See Aen. 3. 121-122 and 400, also 11. 264-65.

27 According to Servius' commentary ad loc., it is unclear what hostis and sedes refer to. My translation is based on Horsfall's interpretation (Horsfall 2006, 125-126). Despite the obscurity of the last verse, we would like to focus on the fact that the whole Virgilian passage shows Idomeneus leaving Crete. A complete interpretation of this verse is unfortunately out of scope of the current research.

${ }^{28}$ This episode is usually juxtaposed to the episode with Jephthah and his daughter (Judges 11:30-39), see Drexler 1894, 107, 51-53. Most probably, there are no parallels in Greek mythology.

${ }_{29}$ Probably the most prominent use of this story was in Mozart's Idomeneo. The European Classicist literature first met Idomeneus in Fénelon's Télémaque. Fénelon followed Servius' version of the myth. In the early $18^{\text {th }}$ century, this motive was further developed in Crébillon's play and several years later Antoine Danchet and André Campra produced a tragédie lyricque Idoménée. The French text was later adapted with minor changes by Giambattista Varesco who wrote libretto for Mozart (however, in contrast to the tragedy by Danchet and Campra, Mozart's opera ends happily with Idomeneus' son surviving). On Mozart's opera, see Heartz 1969 and Mueller 2010. Both authors also address the relation of Idomeneo to the Classicist and Ancient tragedy.

30 Hornblower is surprised that Lykophron ignores the "well-known" story which could explain why Idomeneus left Crete (p. 434). Gantz $(1993,698)$ thinks that this story was invented by Servius.

31 See West 2003, 154 (= Proclus, Chrestomatia, suppl. ex Apoll. epit. 6. 3).

32 See Gundel 1914, 909, 9-49. 
told by him was fostered by scholarly writers who had a taste for rare etiological legends. ${ }^{33}$ Thus, his solutions of Homeric problems, sometimes treated as trivial and superficial, ${ }^{34}$ are, at least partly, to be seen not as a scholarly endeavor but rather as a product of poetic imagination, so typical of his other literary production.

\section{References}

Drexler W. Idomeneus, in: Ausführliches Lexikon der griechischen und römischen Mythologie 1894, II/1, 106-108.

Erbse H. (ed.) Scholia Graeca in Homeri Iliadem. Vol. 1. Berlin, De Gruyter, 1969.

Flashar G., Dubielzig U., Breitenberger B. (trans., ed.) Aristoteles. Fragmente zu Philosophie, Rhetorik, Poetik, Dichtung. Berlin, Akademie Verlag, 2006.

Gantz T. Early Greek Myth: A Guide to Literary and Artistic Sources. Vol. 1. Baltimore, Johns Hopkins University Press, 1993.

Gigon O. Aristotelis Opera. Vol. 3. Berlin - New York, De Gruyter, 1987.

Gottschalk H. B. Heraclides of Pontus. New York, Oxford University Press, 1980.

Gundel H. Idomeneus in: RE 1914, IX/1, 906-909.

Heartz D. The Genesis of Mozart's “Idomeneo”. The Musical Quarterly 1969, 55 (1), 1-19.

Heath M. Heraclides of Pontus on Homer, in: W. W. Fortenbaugh and E. E. Pender (ed.) Heraclides of Pontus: Discussion. New Jersey, Transaction Publishers, 2009, 251-273.

Heubeck A., Fernandez-Galiano M., Russo J.A Commentary on Homer's Odyssey. Vol. III. Oxford, Clarendon Press, $2002\left({ }^{1} 1992\right)$.

Hornblower S. (ed., comm.) Lykophron: Alexandra. Oxford, OUP, 2017.

Horsfall N. Virgil, Aeneid 3: A Commentary. Leiden - Boston, Brill, 2006.

Jacoby F. (ed.) Die Fragmente der Griechischen Historiker II. Leiden, Brill, 1986.

Kennedy G. A. Hellenistic Literary and Philosophical Scholarship, in: G. A. Kennedy (ed.) The Cambridge History of Literary Criticism. Vol. 1. Cambridge, CUP, $1993\left({ }^{1} 1989\right)$.

Kirk G. S. (ed.) The Iliad: A Commentary. Vol. I. Cambridge, CUP, $1995\left({ }^{1} 1985\right)$.

Merkelbach R., West M. L. (ed.) Fragmenta Hesiodea. Oxford, OUP, 1967.

Mueller M. Escape from d-minor: Mozart's Encounter with Ancient Tragedy in "Idomeneo". Arion: A Journal of Humanities and the Classics 2010, 18 (1), 27-54.

Podlecki A. The Peripatetics as Literary Critics. Phoenix 1969, 23 (1), 114-137.

Rzach A. Kyklos, in: RE 1922, XI/2, 2422-2426.

Rose V. (ed.) Aristoteles Pseudepigraphus. Pars 1. Leizig, Teubner, 1863.

Shackleton Bailey D. R. (ed., trans., comm.) Cicero's letters to Atticus. Vol. VI. Cambridge, CUP, 1987.

Schmidt M. (ed.) Hygini Fabulae. Jena, Hermann Dufft, 1872.

Schrader (ed.) Porphyrii Quaestionum Homericarum ad Iliadem pertinentium reliquias. Fasc. 1. Leipzig, Teubner, 1880.

Schütrumpf E. (ed.) Heraclides of Pontus. Texts and translations. New Brunswick, N. J., Transaction Publishers, 2008.

Stocker A. F., Travis A.H. (ed.) Servianorum in Vergilii Carmina Commentariorum. Vol. 3. Oxford, OUP, 1965.

Stoll H. Leukos, in: Ausführliche Lexikon der griechischen und römischen Mythologie II/2, 1897, 2011.

Visser E. Homers Katalog der Schiffe. Stuttgart — Leipzig, Teubner, 1997.

Wagner R. (ed., comm.) Apollodori Bibliotheka. Leipzig, Teubner, 1926.

Wehrli, F. (ed., comm.) Herakleides Pontikos. Die Schule des Aristoteles 7. Basel, Schwabe \& Co. Verlag, 1953.

Wehrli F. Herakleides der Pontiker, in: RE 1968, Suppl. 11, 675-686.

West M. (ed., trans.) Greek Epic Fragments From the Seventh to the Fifth Centuries BC. London - Cambridge, Ma, HUP, 2003.

Received: November 12, 2019

Accepted: March 19, 2020

${ }^{33}$ Following Plutarch who explicitly states that the Alexandrian scholars referred to Heraclides (Alex. 26).

${ }^{34}$ Gottschalk 1980, 136 with references. 